\title{
Chemical composition and antimicrobial activity of essential oils in Xerophytic plant Cotula cinerea Del (Asteraceae) during two stages of development: flowering and fruiting
}

\author{
Chouikh Atef ${ }^{1 *}$, Mayache Boualem ${ }^{2}$, Maazi Mohamed Cherif ${ }^{3}$, Hadef Youcef ${ }^{4}$, Chefrour Azzedine ${ }^{3.4}$ \\ ${ }^{1}$ Dept. of Biology, Faculty of Natural Science and Life, University of Echahid Hamma Lakhder-El Oued, BP 789 El-Oued (39000) Algeria. ${ }^{2}$ Dept. of \\ Biology, Faculty of Natural Science and life, University of Jijel (18000) Algeria. ${ }^{3}$ Faculty of Natural Science and life, University of Mohamed Cherif \\ Messaadia-Souk Ahras (41000) Algeria. ${ }^{4}$ Laboratory Development and Control of Hospital Pharmaceutical Preparations. Medical Science Faculty, \\ University of Badji Mokhtar- Annaba, LP 205 Ezzafrania, Annaba (23000) Algeria.
}

\author{
ARTICLE INFO \\ Article history: \\ Received on: 23/11/2014 \\ Revised on: 07/12/2014 \\ Accepted on: 04/02/2015 \\ Available online: 28/03/2015 \\ Key words: \\ Cotula cinerea Del; Essential \\ oil (EO); GCMS; \\ Antibacterial; Flowering; \\ Fruiting.
}

\begin{abstract}
The essential oil (EO) of Cotula cinerea Del collected in the region of Oued Souf (South-eastern Algeria) during two stages (flowering and fruiting), gave a performance that are $0.0801 \% \pm 0.0117 \%$ at the flowering stage; and $0.391 \% \pm 0.0664 \%$ at the fruiting stage. The chemical study of the (EO) of C. cinerea Del, analyzed by GCMS, showed the presence of 22 chemical compounds in the flowering period with the dominance of: 3-Carène (30.99\%), Thujone $(21.73 \%)$, Santolina triene $(18.58 \%)$ and Camphor $(6.21 \%)$. While 21 chemical compounds were obtained during the fruiting period with the dominance: Thujone (28.78\%), 3-Carène (15.90\%), Eucalyptol (15.13\%), Santolina triene (13.38\%) and Camphor (7.49\%).Viewpoint chemical kinetics and composition, it was noticed that during the flowering stage the plant has produced eight compounds that are absent during the fruiting period. While seven other compounds appeared only during fruiting. It appears the antibacterial of (EO) has $C$. cinerea Del The sensitivity of the bacterial strains tested ; And E. faecium, E.coli, M. morganii, P. vulgaris, $S$. aureus and A. baumannii has shown great sensitivity; the strain $P$. aeruginosa have shown stiff resistance with every concentrations of (EO). As we did not notice any differences significant in the diameters of inhibition with all strains in two stages of growth.
\end{abstract}

\section{INTRODUCTION}

Cotula cinerea Del is one of 03 species belonging to the genus Cotula (Asteraceae) existing in Algeria [Syn. Brocchia cinerea (Del) Vis.] (Dendougui et al., 2012; Maiza et al., 1993) . It is a common Saharo-arabic species that grows in the Sahara desert and sandy areas (Quezel and Santa, 1963). Among these regions Oued Souf (Halis, 2007; Ozenda, 1977) where it is locally known as (Shihia/Shihit El Ebel) (Halis, 2007). It is an annual herbaceous woolly plant (Bensizerara et al., 2012) of 5$15 \mathrm{~cm}$ completely tomentose. Its stems are erect or diffuse. The

* Corresponding Author

Chouikh Atef, Dept. of Biology, Faculty of Natural Science and Life,

University of Echahid Hamma Lakhder-El Oued, BP 789 El-Oued

(39000) Algeria. Email: atchouikh@yahoo.fr leaves and whitish-green stems are covered with tiny hairs (Quezel and Santa, 1963), thick, velvety small leaves, whole are cut into three to seven teeth or "fingers" (Benhammou, 2012) and in the shaft of high branch yellow inflorescences (Quezel and Santa, 1963; Halis, 2007). This plant contains many chemical compounds with therapeutic benefits such as flavonoids (Dendougui et al., 2012), terpenes and essential oils that give plant odor specificity (Markouk et al., 1999). Leaf extracts are Cotula cinerea Del are effective against pathogenic microscopic fungi, they have insecticidal activity on the insect larvae (Bouziane, 2002). This species is widely used in traditional Moroccan medicine for its biological properties such as anti-inflammatory, analgesic, antiseptic, antibacterial, antipyretic (Benhammou, 2012), it can be used to treat stomach pain, fever, headaches, migraines, cough and joint inflammation (Chouikh and Chefrour, 2014). 
The aims of this study highlight the potential fluctuations in yields of essential oils of Cotula cinerea Del and chemical composition, and estimate of Antimicrobial activity of essential oils in two phases of growth: flowering and fruiting.

\section{METHODS AND MATERIAL}

\section{Plant material}

The plant material consists of the aerial part of the plant Cotula cinerea Del; harvested in Oued Souf Sahara (South East of Algeria) during two stages (flowering period in February 2010, and fruiting in April 2010).

\section{Extraction of Essential Oils}

The plant material (100g MS) is subjected to extraction by steam distillation in a Clevenger-type apparatus (Clevenger, 1928). The distillation was carried out for four hours in accordance with the recommendations of the European Pharmacopoeia (AFNOR, 2000 ; Lmachraa et al., 2014; Velasco-Negueruela and Perez-Alonso, 1990). The extractions were repeated five times to confirm the return earned by the mode used. The essential oil is stored and maintained optimally at $4{ }^{\circ} \mathrm{C}$ protected from light (Moumni et al., 2013a).

According to (Moumni et al., 2013b) the performance of the essential oil, expressed in $\mathrm{ml}$ per $100 \mathrm{~g}$ of dry matter of Cotula cinerea Del, and calculated by the following equation:

$$
\mathrm{T}_{\mathrm{EO}}=\left\{\mathrm{V} / \mathrm{M}_{\mathrm{S}} \times 100\right\} \pm\left\{\Delta \mathrm{V} / \mathrm{M}_{\mathrm{S}} \times 100\right\}
$$

$\mathrm{T}_{\mathrm{EO}}$ : Performance of the essential oil.

$\mathrm{V}$ : volume of essential oil collected $(\mathrm{ml})$.

$\Delta \mathrm{V}$ : Reading error.

MS: dry plant mass (g).

\section{Chemical characterization of essential oil by GC/MS}

The essential oil of Cotula cinerea Del was analyzed by chromatography phase gas (Trace GC Ultra) coupled to a mass spectrometer (Polaris Q ion trap MS). The database used for the identification of chemical compounds and measurements of peak areas obtained is that of NIST / EPA / NIH MS LIBRARY (NIST 05 ) and also AMDIS version $2.0 \mathrm{~d}$.

\section{Antimicrobial activity}

Antimicrobial activity of $C$. cinerea essential oils were determined by agar disc diffusion method (Malabadi et al., 2012), Filter paper discs (Whatman $\mathrm{N}^{\mathrm{o}} 3$ and $6 \mathrm{~mm}$ in diameter) were sterilized by autoclaving (Malabadi et al. 2012).

The different concentrations of essential oils (1/1: $100 \%$; 1/2: $50 \% ; 1 / 4: 25 \% ; 1 / 8: 12.5 \% ; 1 / 16: 6.25 \% ; 1 / 32: 3.12 \%)$ were easing by DMSO (Di Methyl Sulf Oxide); this concentrations tested against set of pathogenic bacteria: two Grampositive bacteria: Staphylococcus aureus (S. aureus), Enterococcus faecium (E. faecium), seven Gram-negative bacteria: Escherichia coli (E. coli), Morganella morganii (M. morganii), Citrobacter freundii (C. freundii), Pseudomonas aeruginosa (P. aeruginosa), Proteus vulgaris (P. vulgaris), Acinetobacter baumannii (A. baumannii) and (K. pneumonia). The pure bacterial strain was obtained from Laboratories of microbiology, Medical Science Faculty, University of Badji Mokhtar - Annaba, Algeria. The plates were evaluated after incubation at $37^{\circ} \mathrm{C}$ for $24 \mathrm{~h}$ after which the zones of inhibition around each disc were measured in mm (Malabadi et al. 2012).

\section{RESULTS AND DISCUSSION}

Organoleptic characteristics of the essential oil extracted:

Essential oils are viscous and persistent odor Pleasant Artémises (Table 1), yellow in flowering and Yellowish Green in fruiting during; the color is strongly influenced by the nature of the complex mixture of oil compounds (Ashnagar et al., 2007).

\section{The yield of essential oils:}

The essential oil yield is very low during flowering $(0.0801 \% \pm 0.0117 \%)$ compared to the fruiting period $(0.391 \% \pm$ $0.0664 \%$ ) (Fig. 1). It is relatively higher than those obtained by Kether and colleagues (Kether et al., 2012) working on different parts of Cotula coronopifolia L. in Tunisia ( $0.01134 \%$ in leaves; $0.03935 \%$ for flowers; $0.00123 \%$ in the roots and $0.00405 \%$ for the rods).

\section{Chemical composition of essential oils of Cotula cinerea Del}

The results of the analysis by GCMS showed that the essential oil of the flowering period (Table 2) contains 22 chemical compounds whose major constituents are: 3-Carène (30.99\%), Thujone $(21.73 \%)$, Santolina triene $(18.58 \%)$ and Camphor $(6.21 \%)$. Other compounds are present with low percentages such as: Eucalyptol (2.79\%); 7'-Oxaspiro[cyclopropane-1,4'tricyclo[3.3.1.0(6,8)]nonan-2'-one] $\quad(2.98 \%)$; Terpinen-4-ol (3.64\%); $\rho$-Menth-1-en-8-ol (3.01\%) and Trans-Pinocarveol $(1.28 \%)$. The collection of the plant in the fruiting period allowed us to obtain the essential oils containing 21 compound s. The major substances are: Thujone (28.78\%); 3-Carène (15.90\%), Eucalyptol (15.13\%); Santolina triene (13.38\%) and Camphor (7.49\%). In second position, five compounds are present with average proportions such as: $M$-Cymene (3.34\%); 7'-Oxaspiro [cyclopropane-1,4'-tricyclo[3.3.1.0(6,8)] nonan-2'-one] (3.31\%); 4(10)-Thujen-3-ol, stereoisomer (1.47\%); Terpinen-4-ol (4.26\%) and $p$-Menth-1-en-8-ol (1.65\%). Other compounds are present in small amounts: Origanene; Pinene; Camphene; beta-Phellandrene; 3-Thujanone; Isoborneol; $p$-Cymen-8-ol and 1,2,2,3Tetramethylcyclopent-3-enol.

The chemotype obtained during the two periods of plant development is different in regard to chemical compounds and their percentages. The collection of the plant at the flowering stage allowed us to obtain an essential oil dominated by four compounds chapoter by: 3-Carène (30.99\%); Camphor (6.21\%); Thujone $(21.73 \%)$ and Santolina triène $(18.58 \%)$, whereas fruiting stage Thujone prevails with a percentage of $(28.78 \%)$ followed by 3 Caréne (15.90\%); Eucalyptol (15.13\%); Santolina triene $(13.38 \%)$ and Camphor $(7.49 \%)$. The results obtained during fruiting are in 
agreement with the data of Tadrent et al., (2014) working on Cotula cinerea of Morocco whose chemotype is Thujone (41.4\%); and El Bouzidi et al., (2011) whose major compound is the TransThujone $(41.4 \%)$. Note that in the fruiting period (Figure 02): There is a significant increase in compound s: Eucalyptol; mCymene and Thujone; also a non-significant increase of: 3Thujanone ; 7'-Oxaspiro[cyclopropane-1,4'-tricyclo[3.3.1.0(6,8)] nonan-2'-one] ; Camphor and Terpinen-4-ol. A net decrease in the production of some compounds was observed: 3-Carene; p-Menth1-en-8-ol and Santolina triene. The same is attributed to:1,2,2,3Tetramethylcyclopent-3-enol; p-Cymen-8-ol; 2-Isopropenyl-5methyl-4-hexenyl acétate. With respect to $n$-Valeric acid cis-3-hexenyl ester, the rate remained the same in both periods.
The plant produced 08 compounds during the flowering period [ Trans-Pinocarveol ; Cis-3-Hexenyl Butyrate ; Isobornyl Propanoate; cis-Piperitol; Cuminic alcohol; Carvacrol; pMenthane-1,2,3-triol ; Limonen-6-ol, Pivalate]. While 07 new compounds appeared during the fruiting period [ 4(10)-Thujen-3ol, stereoisomer; Origanene; Pinene; Camphene; betaPhellandrene ; Isoborneol ; (+)-trans-Chrysanthenyl Acetate]. The essential oil of Cotula cinerea Del is characterized by changes in the chemotype, due to various factors including for example: the part of the plant used (drugs), stage of plant development (Hammoudi and Hadj Mahammed, 2010), genetic factors (Lmachraa et al., 2014), the environment and the harvest period and the nature of the soil (Fellah et al., 2006).

Table 1: organoleptic characteristics of the essential oil of Cotula cinerea Del.

\begin{tabular}{lccccc}
\hline & \multicolumn{4}{c}{ organoleptic characteristics } \\
\cline { 2 - 5 } Essential oils of Cotula cinerea Del & & Appearance & Color & Odor \\
\cline { 2 - 5 } & Flowering & liquid & Yellow & Pleasant Artémises & Sweet \\
& fruiting & Liquid & Yellowish Green & Pleasant Artémises & Sweet \\
\hline
\end{tabular}

Table 2: Chemical composition of essential oils of Cotula cinerea Del collected in during flowering and fruiting.

\begin{tabular}{|c|c|c|c|c|c|c|c|c|}
\hline \multicolumn{5}{|c|}{ flowering } & \multicolumn{4}{|l|}{ fruiting } \\
\hline$N^{\circ}$ & Ret Time & area & area $\%$ & compounds & Ret Time & area & area $\%$ & compounds \\
\hline 01 & 7.211 & 2868758 & 0.30 & m-Cymene & 3.395 & 127438434 & 4.22 & Santolina triene \\
\hline 02 & 7.449 & 26517689 & 2.79 & Eucalyptol & 3.880 & 6943898 & 0.23 & Origanene \\
\hline 03 & 9.011 & 3383662 & 0.36 & Cis-3-Hexenyl Butyrate & 4.034 & 14288331 & 0.47 & Pinene \\
\hline 04 & 10.089 & 3472222 & 0.37 & 3-Thujanone & 4.373 & 11056004 & 0.37 & Camphene \\
\hline 05 & 10.663 & 206241956 & 21.73 & Thujone & 5.175 & 6375286 & 0.21 & beta.-Phellandrene \\
\hline 06 & 10.884 & 28277266 & 2.98 & $\begin{array}{l}\text { 7'-Oxaspiro [cyclopropane-1,4'- } \\
\text { tricyclo[3.3.1.0(6,8)]nonan-2'- } \\
\text { one] }\end{array}$ & 6.936 & 100935774 & 3.34 & m-Cymene \\
\hline 07 & 11.394 & 58970182 & 6.21 & Camphor & 7.247 & 457541014 & 15.13 & Eucalyptol \\
\hline 08 & 11.782 & 12147362 & 1.28 & Trans-Pinocarveol & 9.878 & 30022904 & 0.99 & 3-Thujanone \\
\hline 09 & 12.780 & 7575998 & 0.80 & Isobornyl Propanoate & 10.687 & 869869318 & 28.78 & $\begin{array}{l}\text { Thujone } \\
\text { 7'- }\end{array}$ \\
\hline 10 & 13.167 & 176332161 & 18.58 & Santolina triene & 10.831 & 100013514 & 3.31 & $\begin{array}{l}\text { Oxaspiro[cyclopropane- } \\
1,4^{4} \text { - } \\
\text { tricyclo[3.3.1.0(6,8)]non } \\
\text { an-2'-one] }\end{array}$ \\
\hline 11 & 13.421 & 34578305 & 3.64 & Terpinen-4-ol & 11.356 & 226506241 & 7.49 & Camphor \\
\hline 12 & 13.551 & 7814366 & 0.82 & p-Cymen-8-ol & 11.689 & 44462471 & 1.47 & $\begin{array}{l}\text { 4(10)-Thujen-3-ol, } \\
\text { stereoisomer }\end{array}$ \\
\hline 13 & 13.976 & 28587584 & 3.01 & p-Menth-1-en-8-ol & 12.659 & 18483050 & 0.61 & Isoborneol \\
\hline 14 & 14.077 & 6126622 & 0.65 & $\begin{array}{l}\text { 1,2,2,3-Tetramethylcyclopent-3- } \\
\text { enol }\end{array}$ & 13.155 & 277084938 & 9.16 & Santolina triene \\
\hline 15 & 14.810 & 5635594 & 0.59 & Cis-Piperitol & 13.375 & 128820727 & 4.26 & Terpinen-4-ol \\
\hline 16 & 16.249 & 5348508 & 0.56 & $\begin{array}{l}\text { N-Valeric Acid Cis-3-Hexen-1- } \\
\text { Y1 Ester }\end{array}$ & 13.490 & 9205742 & 0.30 & p-Cymen-8-ol \\
\hline 17 & 18.215 & 294131766 & 30.99 & 3-Carene & 13.926 & 49927844 & 1.65 & $\begin{array}{l}\text { p-Menth-1-en-8-ol } \\
1,2,2,3 \text { - }\end{array}$ \\
\hline 18 & 18.296 & 4549808 & 0.48 & Cuminic alcohol & 14.055 & 7294071 & 0.24 & $\begin{array}{l}\text { Tetramethylcyclopent-3- } \\
\text { enol }\end{array}$ \\
\hline 19 & 18.858 & 13109553 & 1.38 & $\begin{array}{l}\text { 2-Isopropenyl-5-methyl-4- } \\
\text { hexenyl acetate }\end{array}$ & 16.187 & 17233248 & 0.57 & $\begin{array}{l}\text { n-Valeric acid cis-3- } \\
\text { hexenyl ester }\end{array}$ \\
\hline 20 & 19.139 & 5465117 & 0.58 & Carvacrol & 17.210 & 10620966 & 0.35 & $\begin{array}{l}\text { (+)-trans-Chrysanthenyl } \\
\text { Acetate }\end{array}$ \\
\hline 21 & 25.607 & 5103929 & 0.54 & p-Menthane-1,2,3-triol & 18.233 & 480658650 & 15.90 & 3-Carène \\
\hline 22 & 27.385 & 8910561 & 0.94 & Limonen-6-ol, pivalate & 18.852 & 24515661 & 0.81 & $\begin{array}{l}\text { 2-Isopropenyl-5-methyl- } \\
\text { 4-hexenyl acetate }\end{array}$ \\
\hline Sum & & & $99.58 \%$ & & & & $99.86 \%$ & \\
\hline
\end{tabular}




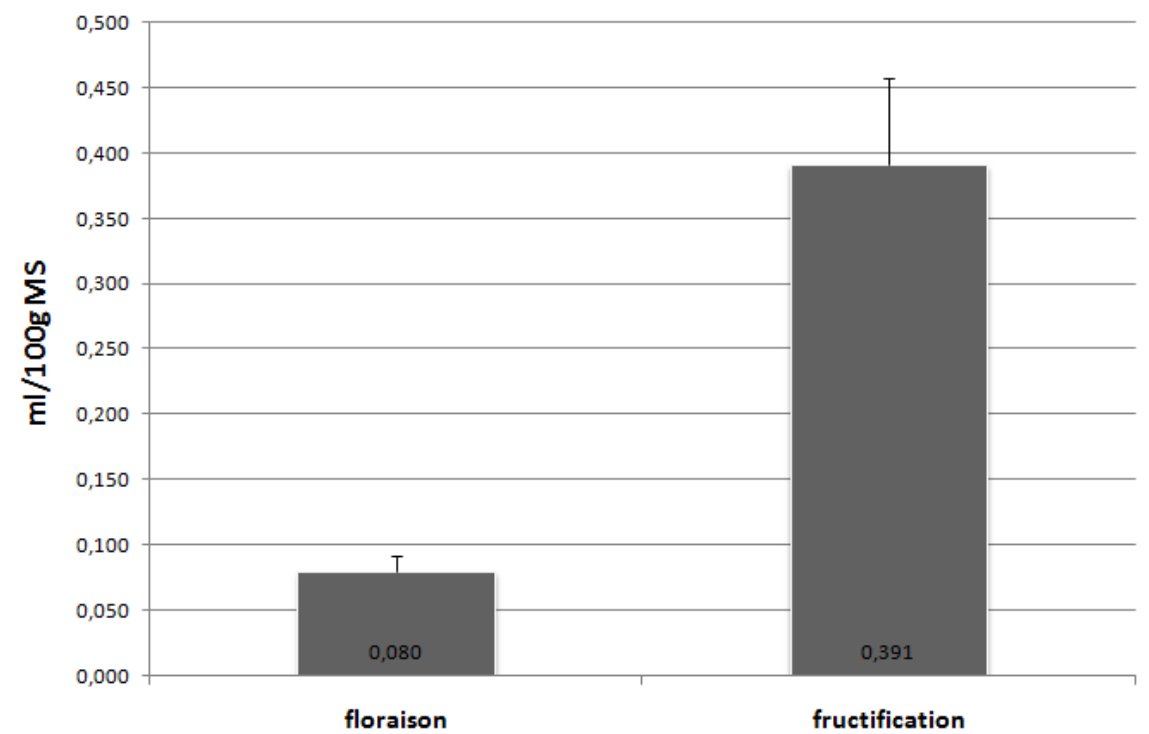

Fig. 1: Yield of essential oils from the aerial part of Cotula cinerea Del of Oued Souf region (Algeria)

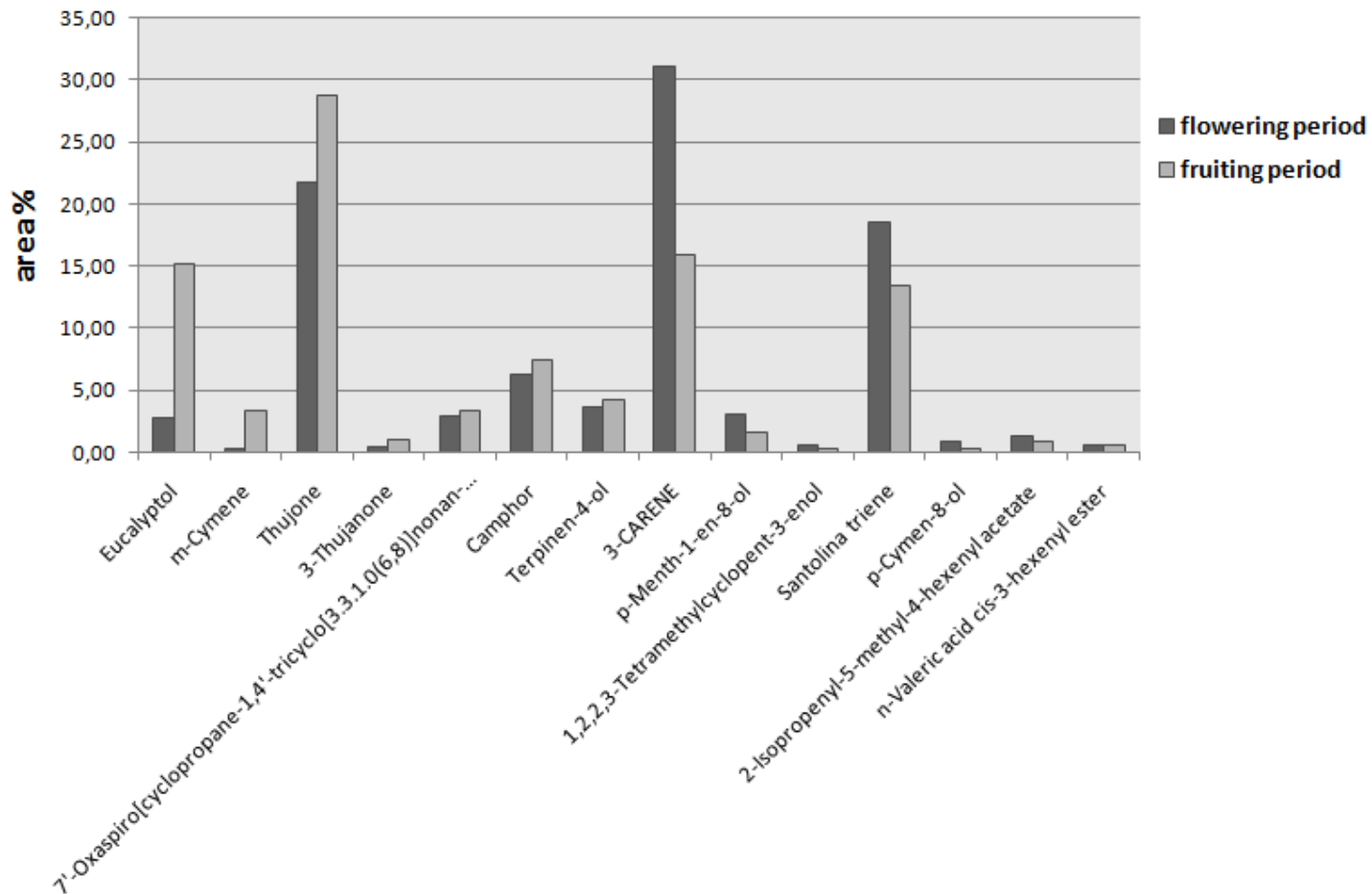

Fig. 2: Kinetics and variation in the chemical composition of the essential oils of Cotula cinerea Del obtained during the two stages of development.

Table 3: Inhibition by essential oils of Cotula cinerea Del obtained during the two stages of development. (zone size, mm). (IMP: Imipénème), (PEF : Péfloxacine), (L: Lincomycine), (RA: Rifampicine).

\begin{tabular}{|c|c|c|c|c|c|c|c|c|c|c|c|c|c|c|c|c|c|c|c|c|}
\hline \multirow{3}{*}{ Test bacteria } & \multicolumn{16}{|c|}{ Different concentrations of the essential oils } & \multirow{2}{*}{\multicolumn{4}{|c|}{ Antibiotics }} \\
\hline & \multicolumn{8}{|c|}{ Flowering period } & \multicolumn{8}{|c|}{ fruiting period } & & & & \\
\hline & DMSO & $\begin{array}{c}\text { Disc } \\
\text { empty }\end{array}$ & $1 / 1$ & $1 / 2$ & $1 / 4$ & $1 / 8$ & 1/16 & $1 / 32$ & DMSO & $\begin{array}{c}\text { Disc } \\
\text { empty }\end{array}$ & $1 / 1$ & $1 / 2$ & $1 / 4$ & $1 / 8$ & 1/16 & $1 / 32$ & IMP & PEF & $\mathbf{L}$ & $\mathbf{R A}$ \\
\hline E.coli & 6 & 6 & 50 & 50 & 50 & 50 & 16 & 12 & 6 & 6 & 50 & 50 & 50 & 50 & 18 & 13 & - & - & - & - \\
\hline M. morganii & 6 & 6 & 50 & 50 & 50 & 28 & 16 & 13 & 6 & 6 & 50 & 50 & 45 & 27 & 15 & 10 & - & - & - & - \\
\hline C. freundii & 6 & 6 & 50 & 50 & 21 & 15 & 15 & 11 & 6 & 6 & 50 & 50 & 23 & 19 & 14 & 9 & - & 40 & - & - \\
\hline P. aeruginosa & 6 & 6 & 18 & 15 & 12 & 10 & 8 & 6 & 6 & 6 & 18 & 9 & 9 & 9 & 7 & 6 & 21 & 06 & - & - \\
\hline P. vulgaris & 6 & 6 & 47 & 45 & 28 & 21 & 13 & 11 & 6 & 6 & 47 & 46 & 41 & 37 & 18 & 11 & - & - & - & - \\
\hline E. faecium & 6 & 6 & 50 & 50 & 50 & 50 & 50 & 47 & 6 & 6 & 50 & 50 & 50 & 50 & 50 & 50 & & & 32 & \\
\hline S. aureus & 6 & 6 & 50 & 50 & 50 & 49 & 16 & 12 & 6 & 6 & 50 & 50 & 50 & 50 & 15 & 10 & - & - & - & - \\
\hline A. baumannii & 6 & 6 & 50 & 50 & 50 & 50 & 18 & 10 & 6 & 6 & 50 & 50 & 50 & 50 & 18 & 10 & - & 18 & - & 20 \\
\hline K. pneumonia & 6 & 6 & 50 & 50 & 50 & 16 & 15 & 12 & 6 & 6 & 50 & 50 & 50 & 17 & 15 & 12 & - & 30 & - & - \\
\hline
\end{tabular}


Antimicrobial activity of essential oils of Cotula cinerea Del obtained during the two stages of development

Through the results listed in the table (03) conclude that:

- $\quad$ E. faecium showed great sensitivity to all with essential oil concentrations where arrived in $(50 \mathrm{~mm})$, which was larger than the diameter discourage antibiotic (Lincomycine: $32 \mathrm{~mm}$ ).

- $\quad$ The strains E.coli, M. morganii, P. vulgaris, S. aureus and $A$. baumannii has shown great sensitivity to concentrations $\quad(1 / 1,1 / 2,1 / 4,1 / 8) \quad$ Where diameter of inhibition ranged between $(50 \mathrm{~mm}$ to 21 $\mathrm{mm}$ ), while this strains have shown considerable resistance with concentrations(1/16and 1/32).

- $C$. freundii and $K$. pneumonia shown great sensitivity to concentrations $(1 / 1,1 / 2,1 / 4)$ where diameter of inhibition arrived to $50 \mathrm{~mm}$, as shown resistance medium with concentrations $(1 / 8,1 / 16$, 1/32) Where ranged diameter of inhibition ( $16 \mathrm{~mm}$ to 11 $\mathrm{mm})$.

- $\quad$. aeruginosa have shown stiff resistance with every concentrations of essential oil and increased the intensity of this resistance especially with concentrations of essential oil in the fruiting stage.

- Comparing the results of the study of antibacterial of essential oils extracted in two phases: flowering and fruiting, did not record any differences significant in the diameters of inhibition with all strains, except for those registered with $P$. aeruginosa Where showed stiff resistance with all concentrations of essential oil in Phase fruiting compared with concentrations of essential oil in stage of flowering.

- The values of diameters of inhibition were great and arguing with most concentrations compared with diameters of inhibition recorded antibiotics used except antibiotic (Imipénème) with $P$. aeruginosa, which gave diameters of inhibition $(21 \mathrm{~mm})$ larger than the diameter suppressive effect of different concentrations of essential oil of flowering and fruiting stages with this strain.

Comparing our results with the results obtained by:

- Bouabdelli et al., (2012) Who experienced several extracts (infusion; decoction; maceration; percolation) on: E.coli and S. aureus gave diameters small inhibitory Compared diameters obtained where you get to Higher diameter inhibition ( $20 \mathrm{~mm} \mathrm{E.coli} \mathrm{with} \mathrm{and}$ $17 \mathrm{~mm}$ with $S$. aureus); As with strain P. aeruginosa the results were close $(14 \mathrm{~mm})$.

- Bensizerara et al., (2012) Who experienced different extracts (petroleum ether; ethanol 70\%; n-butanol; ethyl acetate) on: E.coli; K. pneumonia and S. aureus gave diameters small inhibitory Compared diameters obtained where you get to Higher diameter inhibition (13 mm E.coli with, $12 \mathrm{~mm}$ with $S$. aureus and $17 \mathrm{~mm}$ with $K$. pneumonia); As with strain $P$. aeruginosa the results were spaced somewhat $(12 \mathrm{~mm})$.

\section{CONCLUSION}

The chemical study of essential oil of Cotula cinerea Del, harvested in Oued Souf region (North Eastern Algerian Sahara), revealed that the optimum essential oil yield obtained during the fruiting period $(0.391 \% \pm 0.0664 \%)$ is characterized by viscous lingering odor and a yellowish green color while in the flowering period it has a yellow color.

The essential oil of $C$. cinerea Del includes 22 chemicals compounds dominated by: 3-Carène $(30.99 \%)$, Thujone $(21.73 \%)$; Santolina triene $(18.58 \%)$ and Camphor $(6.21 \%)$, while in the fruit, the number is decreased by 21 compounds of which five are in the majority: Thujone (28.78\%); 3-Carène (15.90\%); Eucalyptol (15.13\%); Santolina triene (13.38\%) and Camphor $(7.49 \%)$. During the fruiting phase the plant produced three compounds in excess (Eucalyptol, m-Cymene and thujone), then the ratio is decreased to three other substances (3-Carene, $p$ Menth-1-en-8-ol and Santolina triene). the plant synthesized 08 compounds at flowering stage [Trans-Pinocarveol / Cis-3-Hexenyl Butyrate/ Isobornyl Propanoate/cis-Piperitol/Cuminic alcohol/ Carvacrol / p-Menthane-1,2,3-triol /Limonen-6-ol, Pivalate], This is probably because these substances have a direct relationship with pollination and fertilization, whereas they are dispensable to the fruiting stage.

According to the results, we can conclude that the yield and chemical composition of essential oils have a relationship with intrinsic (genetic factor, harvest stage, state of the plant) and extrinsic factors (soil, climate, flora procession, insect pests and pollinators, human impact, etc ...). It also appears that the antibacterial essential oil has Cotula cinerea Del The sensitivity of the bacterial strains tested by the method of direct contact with the essential oil of Cotula cinerea Del varies from strain to strain; And E. faecium, E.coli, M. morganii, P. vulgaris, S. aureus and A. baumannii has shown great sensitivity; the strain $P$. aeruginosa have shown stiff resistance with every concentrations of essential oil.

As we did not notice any differences significant in the diameters of inhibition with all strains in two stages of growth (flowering and fruiting).

\section{REFERENCES}

Afnor (Agence française de normalisation). 2000. Huiles essentielles. Échantillonnage et méthodes d'analyse (tome 1) Monographies relatives aux huiles essentielles (tome 2). Vol 1 et 2, Paris La Défense : AFNOR, 663p.

Ashnagar A, Gharib N, Foroozanfar S. Isolation and identification of the major chemical components found in the upper parts of Teucrium Polium plants grown in Khuzestan province of Iran. Chinese Journal of Chemistry, 2007; 25:1171-1173.

Benhammou N. 2012. Activité antioxydante des extraits des composés phénoliques de dix plantes médicinales de l'Ouest et du SudOuest Algérien. Université Abou Bakr Belkaïd-Tlemcen, Algérie: Thèse de Doctorat, Pp: 30. 
Bensizerara D, Menasria T, Melouka M, Cheriet L, Chenchouni H. Antimicrobial activity of xerophytic plant (Cotula cinerea Delile, 1831) extracts against some pathogenic bacteria and fungi. Asian Pac J Trop Biomed, 2012;1-5.

Bouabdelli F, Djelloul A, Kaid-Omar Z, Semmoud A, Addou A. Antimicrobial Activity of 22 Plants Used in Urolithiasis Medicine in Western Algeria. Asian Pacific Journal of Tropical Disease, 2012; 530535 .

Bouziane M. 2002. Caractérisation structurale de quelques molécules organiques dans la plante: Cotula cinerea de la région d'Ouargla. Université d'Ouargla, Algérie: Mémoire de magister en Chimie Organique, Faculté des Sciences et Sciences de l'ingénieur, Pp : 48.

Chouikh A, Chefrour A. Seasonal biometric and dynamic monitoring of the Shihia plant Cotula cinerea Del (1831) and its accompanying plants in the Saharan region Oued-Souf (south-east of Algeria). International Journal of Science and Research (IJSR), 2014; 3(7):826-833.

Clevenger J F. Determination of volatile oil. J Ann Pharm Assoc, 1928; 17(4):346-351.

Dendougui H, Seghir S, Jay M, Benayache F, Benayache S. Flavonoides from Cotula cinerea Del. Int J Med Arom Plants, 2012; 2:589-595.

El Bouzidi L, Abbad A, Fattarsi K, Hassani L, Leach D, Markouk M, Legendre L, Bekkouche K. Chemical composition and anticandidal properties of the essential oil isolated from aerial parts of Cotula cinerea: a rare and threatened medicinal plant in Morocco. Nat Prod Commun, 2011; 6(10):1491-1494.

Fellah S, Ramdhane M, Abderraba. Extraction et étude des huiles essentielles de la Salvia officinalis L. cueillie dans deux régions différentes de la Tunisie. J Soc Alger Chim, 2006 ; 193-202.

Halis Y. 2007. Plant Encyclopedia in area Oued Souf: desert plants common in the Big East race. El Oued, Algeria: El Walid, 154-155.

Hammoudi R, Hadj Mahammed M. Contribution à l'étude de la composition chimique des huiles essentielles de la plante Teucrium polium SSP. Geyrii (Lamiaceae). Annales des Sciences et Technologie, 2010; 2(1): 01-05

Kether F BH, Mahjoub M A, Mahjoub S A, Belhaj Salah K, Helal A N, Mighri Z. Chemical composition, in vitro antifungal and antioxidant activities of essential oil from Cotula coronopifolia $\mathrm{L}$. growing in Tunisia. African Journal of Microbiology Research, 2012; 6(20):43884395.
Lmachraa I, Fdil R, Fdil N, Mouzdahir A. Huile essentielle de Santolina africana (Jord. \& Fourr.) du Maroc: Composition chimique et isolement des deux principaux constituants. J Mater Environ Sci, 2014 ; 5 (1):67-72.

Maiza K, Brac de la Perrière RA, Hammiche V. Pharmacopée traditionnelle saharienne: Sahara septentrional. 2nd Proc. of European Conf. On Ethnopharmacology \& 11th In Conf Of Ethnomedecine. Heidelberg France, 1993; 169-171.

Malabadi R B, Mulgund G S, Meti N T, Nataraja K, Kumar S V. Antibacterial activity of silver nanoparticles synthesized by using whole plant extracts of Clitoria ternatea. Research in Pharmacy, 2012; 2(4): $10-21$.

Markouk M, Radwane A, Lazrek HB, Jana M, Benjama A. Antibacterial activity of Cotula cinerea extract. Phytoterapia, 1999; 13:229-230

Moumni M, Elwatik L, Kasimi A R, Homrani Bakali A M. Etude comparative des rendements en huile essentielle D'Artemisia herbaalba Asso a état sauvages et domestique a Errachidia (Sud-Est du Maroc). Science Lib, 2013b ; 5: $\mathrm{N}^{\circ} 130103$.

Moumni M, Elwatik L, Kasimi A R, Homrani Bakali A M. Induction du chemotype a davone de l'huile Essentielle d'armoise blanche (Artemisia herba alba) par domestication à Errachidia (Sud-Est du Maroc). Science Lib, 2013a ; 5: N 130506.

Ozenda P. 1977. Flore du Sahara. Paris, France : CNRS, 630 p. Quezel S, Santa S. 1963. Nouvelle flore de l'Algérie et des régions désertique méridionales (2 tomes). Paris, France : CNRS, 1168 p.

Tadrent W, Kabouche A, Touzani R, Kabouche. Chemotypes investigation of essential oils of "Guertoufa" herbs. J Mater Environ Sci, 2014; 5 (4):1200-1205.

Velasco-Negueruela A, Perez-Alonso M J. The volatiles of six Teucrium species from the iberian peninsula and the balearic islands mediterranean sea. Phytochemistry (oxford), 1990; 29(4):1165-1170.

\section{How to cite this article:}

Chouikh Atef, Mayache Boualem, Maazi Mohamed Cherif, Hadef Youcef, Chefrour Azzedine. Chemical Composition and Antimicrobial activity of Essential Oils in Xerophytic Plant Cotula cinerea Del (Asteraceae) during two stages of development: flowering and fruiting. J App Pharm Sci, 2015; 5 (03): 029-034. 